\title{
A Potentiometric Study of Guanidinoacetic Acid Complexation with the Ions Mn(II), Co(II), Ni(II), Cu(II), Zn(II), Cd(II) and Pb(II)
}

\author{
Judith Felcman*, and Jussara Lopes de Miranda \\ Departamento de Química, PUC/ RJ, Marquês de São Vicente, \\ 225 22453-900 Rio de Janeiro, RJ - Brasil
}

Received: August 2, 1994

\begin{abstract}
Foi estudado a complexação do ácido guanidoacético (AGA) com alguns íons de interesse biológico, a saber : $\mathrm{Mn}(\mathrm{II}), \mathrm{Co}(\mathrm{II}), \mathrm{Ni}(\mathrm{II}), \mathrm{Cu}(\mathrm{II}), \mathrm{Zn}(\mathrm{II}), \mathrm{Cd}(\mathrm{II})$ e $\mathrm{Pb}(\mathrm{II})$. Após o AGA ter sido sintetizado e caracterizado, foram determinadas potenciometricamente as constantes de dissociação deste ligante, assim como a de formação de seus complexos e hidroxicomplexos com os íons supracitados. A maioria dos íons estudados formou complexos do tipo MAGA, M(AGA)2 e $\mathrm{M}(\mathrm{AGA}) 3$. O Zn(II) e o $\mathrm{Cu}$ (II) não formaram as espécies M(AGA)3 e MAGA(OH)3 . A hidrólise dos complexos CuAGA e ZnAGA iniciou-se em pH próximo de 6-7 e para as demais espécies MAGA, em pH próximo de 8 , sendo que após estes valores houve a predominância de espécies polímeras hidrolisadas.
\end{abstract}

The guanidinoacetic acid (GAA) complexation with some ions of biological interest, such as $\mathrm{Mn}$ (II), $\mathrm{Co}(\mathrm{II}), \mathrm{Ni}(\mathrm{II}), \mathrm{Cu}(\mathrm{II}), \mathrm{Zn}(\mathrm{II}), \mathrm{Cd}(\mathrm{II})$ and $\mathrm{Pb}(\mathrm{II})$ has been investigated. GAA was prepared and analysed. The dissociation constants of its complexes and hydroxy complexes with the above ions have been potentiometrically determined. Most of the ions formed complexes of the type MGAA, M(GAA)2 and M(GAA) 3 . Zn(II) and $\mathrm{Cu}(\mathrm{II})$ did not form $\mathrm{M}(\mathrm{GAA})_{3}$ and $\mathrm{M}(\mathrm{GAA})(\mathrm{OH}) 3$. The hydrolysis of CuGAA and ZnGAA begins near $\mathrm{pH}$ 6-7; for the other MGAA complexes it begins near $\mathrm{pH}$ 8. Above these $\mathrm{pH}$ values, polymerized, hydrolysed species predominated.

Keywords: potentiometric titration, guanidinoacetic acid, ions with biological interest

\section{Introduction}

Our interest in the complexation of GAA is based on the fact that this ligand plays an important biological role. GAA is present in our organism and is formed mainly in the kidneys ${ }^{1}$, from the reaction between arginine and glycine catalyzed by amidinotransferase. Also it is known that the final step in the biosynthesis of creatine is the donation of the methyl group from adenosylmethionine to guanidinoacetic acid, catalyzed by guanidinomethyltransferase.

Although the mechanism of synthesis of GAA has not been totally elucidated, some of its properties have already been investigated. It is known that GAA may decrease the plasma cholesterol level in rats fed high cholesterol diets ${ }^{2}$. Besides, its derivatives may be more sensitive markers of the state of chronic renal failures (such as glomerulonephritis, polycistic kidney, diabetic nephropathy, lupus nephritis, renal amyloidosis) by reflecting the activity of the causal renal disease ${ }^{3}$. Other derivatives such as tetrazolyl substituted guanidinoacetic compounds may be potentially used as sweetners ${ }^{4}$. Thus, there are several publications about GAA and its derivatives ${ }^{5,6,7}$, however little is known about its strengh and selectivity of complexation. What follows is a report of the stability constants of the complexes of GAA with some of the essential ions that exist in our body (Mn(II), Co(II), Ni(II), Cu(II), Zn(II)) and others regarded as toxic ions ( $\mathrm{Pb}(\mathrm{II})$ and $\mathrm{Cd}(\mathrm{II}))$. The tendency for some of the complexes to hydrolyse is also reported due to the relevance for biological systems.

\section{Experimental}

\section{Materials}

GAA was synthesized following a well established procedure $^{8}$ and analysed using a 252 Cf PMDS mass spectrometer from the Van Der Graaf Laboratory of Physics 
(PUC / RJ) and using a Perkin-Elmer infrared spectrophotometer coupled with a thermogravimetric balance. The stock solutions of metal ions were prepared with the following analytical grade salts: $\mathrm{MnSO}_{4} .7 \mathrm{H}_{2} \mathrm{O}, \mathrm{Co}\left(\mathrm{NO}_{3}\right)_{2}$. $6 \mathrm{H}_{2} \mathrm{O}$ and $\mathrm{Ni}\left(\mathrm{NO}_{3}\right)_{2} .6 \mathrm{H}_{2} \mathrm{O}$ (Merck), $\mathrm{Cu}\left(\mathrm{NO}_{3}\right)_{2} .3 \mathrm{H}_{2} \mathrm{O}$ (Carlo Erba), $\mathrm{Zn}\left(\mathrm{NO}_{3}\right)_{2} \cdot 6 \mathrm{H}_{2} \mathrm{O}$ and $\mathrm{Pb}\left(\mathrm{NO}_{3}\right)_{2}$ (Vetec) and $\mathrm{Cd}\left(\mathrm{NO}_{3}\right)_{2} \cdot 4 \mathrm{H}_{2} \mathrm{O}$ (Riedel). All of these solutions were prepared with carbonate-free deionized water. The titrant in all cases was a solution of $0.1 \mathrm{M}$ carbonate-free potassium hydroxide, prepared directly from Merck Darmstadt titrisol ampoules.

The titrimetric data were obtained using an E386 multihand semiautomatic microburette, a B375 Micronal potentiometer and a combined glass electrode. The glass electrode was calibrated before each titration with a pair of Merck standard buffer solutions in nitrate medium: the first of pH 7.00 (the same as the solution in the bulb) and the second of $\mathrm{pH} 4.00$. A reliable accuracy was achieved using this procedure inasmuch as the selected reference solutions had $\mathrm{pH}$ values which lay on either side of the values expected to form the central position of the titration ${ }^{9}$.

We maintained the ionic strengh constant in the medium of all solutions using a $0.1 \mathrm{M}$ potassium nitrate solution of analytical grade (Merck). All titrations were performed at $25{ }^{\circ} \mathrm{C}$ by coupling the titration cell with a thermostat calibrated at this temperature.

\section{Method}

\section{pH titration procedure}

Proton and metal stability constants were determined by potentiometric titration of the ligand in the presence and absence of metal ions, with carbonate-free potassium hydroxide (see Figs. 1 and 2). The metal ion concentration was in the range $5-10 \times 10^{-2} \mathrm{M}$, while the ligand concentration did not exceed four times that of the metal ions in the majority of the systems.

Solutions containing guanidinoacetic acid and metal ions were titrated in metal:ligand ratios $1: 1,1: 2,1: 3$ and $1: 4$.

\section{Calculations}

For each chemical species $\mathrm{M}_{\mathrm{p}} \mathrm{L}_{\mathrm{q}} \mathrm{H}_{\mathrm{r}}$ in the solution equilibria there is a chemical constant, the formation constant, which is expressed (charges were omitted for simplicity) as follows:

$$
\beta_{\mathrm{pqr}}=\frac{\left[\mathrm{M}_{\mathrm{q}} \mathrm{L}_{\mathrm{p}} \mathrm{H}_{\mathrm{r}}\right]}{\left[\mathrm{M}^{\mathrm{P}}[\mathrm{L}]^{\mathrm{q}}[\mathrm{H}]^{\mathrm{r}}\right.}
$$

Because the thermodynamic definition of a formation constant utilizes activities (and not concentrations, as given above), the quotient of the activity coefficients was kept constant by performing the experiments with a medium of constant ionic strengh.
The formation constants of all species were obtained and refined using the SUPERQUAD ${ }^{10}$ program. A chemical model, in agreement with previous studies ${ }^{11}$, was mounted and the data from the potentiometric titrations was entered in the program. The SUPERQUAD program itself has some model selection criteria. If, for example, after refinement a formation constant is found to be ill-defined, a new model is automatically generated. For further explanations see Ref. 10 .

\section{Results and Discussion}

The dissociation constants of GAA were determined using $10^{-3} \mathrm{M}, 3 \times 10^{-3} \mathrm{M}$ and $4 \times 10^{-3} \mathrm{M}$ solutions and are listed in Table 1 . The calculated stepwise equilibrium constants for all systems are also listed in Table 1. The initial model for each system was that which is commonly found for other correlated aminoacids such as glycine, arginine ${ }^{12}$ etc. We investigated the possible formation of the species $\mathrm{ML}, \mathrm{ML}_{2}$ and $\mathrm{ML}_{3}$, the protonated and the hydrolysed species. The protonated species $\mathrm{MH}_{2} \mathrm{~L}$ was introduced in our model because it was observed that the titration curves had initial values of $\mathrm{pH}$ higher than expected. Assuming that hydrolysis begins with the loss of protons from water molecules coordinated to the complex and that this is followed by dimerization and subsequent polymerization, it is then obvious that this process involves a complex equilibrium. On the other hand, it was of interest to evaluate the $\mathrm{pH}$ range where hydrolysis process initiated. Thus, using only the part of the titration curve (1:1 metal:ligand ratio) where hydrolysis was not yet intense, it was possible to set up a model with the simplest hydrolysed species : $\mathrm{MLOH}, \mathrm{ML}(\mathrm{OH})_{2}, \mathrm{ML}(\mathrm{OH})_{3}$ and $\mathrm{M}_{2} \mathrm{~L}_{2}(\mathrm{OH})_{2}$. However, the formation of some species depends on the coordination number of the metal and for this reason it is more appropriate to discuss them separately.

\section{Manganese, Cobalt, Nickel and Cadmium systems}

For these systems, the possible formation of the species $\mathrm{ML}, \mathrm{MH}_{2} \mathrm{~L}, \mathrm{MLOH}, \mathrm{ML}(\mathrm{OH})_{2}, \mathrm{ML}(\mathrm{OH})_{3}$ and $\mathrm{M}_{2} \mathrm{~L}_{2}(\mathrm{OH})_{2}$ in the systems of the metal:ligand ratio 1:1 was investigated. The formation of some of the species was confirmed, but they were formed at different $\mathrm{pH}$ values. This was indicated by the points of the titration curve used in the computer program to calculate each of these species. The hydroxy complex MLOH was calculated together with the ML species, which was expected considering that the first hydrolysis step should occur at $\mathrm{pH}$ values close to those of ML formation. The other species were calculated separately using higher $\mathrm{pH}$ values. A final refinement for each metal ion was done using all of these constants and beginning with all titration points, resulting in the values presented in Table 1. Observing these values, one can note that the refinement of the formation constant of $\mathrm{Co}(\mathrm{GAA})(\mathrm{OH})_{3}$ led to an excessive standard deviation 
$( \pm 0.8)$. Indeed, it is very difficult to calculate good values of highly hydrolysed species. We could presume that the hydrolysis process of MGAA complexes should be fast, favouring the rapid formation of a polymeric species. For the nickel and cadmium systems the presence of the $\mathrm{ML}(\mathrm{OH})_{3}$ species was not confirmed and the program itself has removed it from the equilibria equations, generating a new model without it.

The species $\mathrm{ML}_{2}$ and $\mathrm{ML}_{3}$ for $\mathrm{Mn}(\mathrm{II}), \mathrm{Co}(\mathrm{II}), \mathrm{Ni}(\mathrm{II})$ and $\mathrm{Cd}(\mathrm{II})$ were found using the titration data of metal:ligand ratio $1: 2$ and $1: 3$, respectively.

\section{Copper and Zinc systems}

In these cases the formation of the $\mathrm{ML}(\mathrm{OH})_{3}$ species was rejected by the program on the very first attempt. The analysis of the species distribution as a function of $\mathrm{pH}$ for these systems shows that the protonated species - $\mathrm{MH}_{2} \mathrm{~L}$ were predominant until $\mathrm{pH}$ 6. Then ML formation was observed, followed by hydrolysis, which began near $\mathrm{pH} 6$ for CuGAA and near pH 7 for ZnGAA.

\section{Lead system}

This was a special system because only the ML, ML2 and $\mathrm{ML}_{3}$ species could be calculated. It was not possible to calculate the hydrolysed species concentrations even though it is thought that they exist in the equilibrium. This is due to the formation of a large quantity of precipitate during the titration, which prevented continuation of the titration until higher $\mathrm{pH}$ values. The precipitate indicates the formation of a polymeric, hydrolysed species at low $\mathrm{pH}$ values.

\section{Coordination groups}

The protonation constants of GAA and their complexes are listed in Table 1. The dissociation constants of GAA in a 50-50\% alcohol-water medium and its formation constant with uranyl ion are the only reported values at present. Considering all the potential donor sites that exist in GAA moiety, the coordination of this ligand to the metal ions may be of four types: 1 ) through the $\alpha$-nitrogen and oxygen of the carboxylate group, forming a five membered ring shown in Structure I; 2) through the $\alpha$-nitrogen and another nitrogen of the guanidino group, forming a four-membered ring (Structure II), 3) through both nitrogens of the guanidino group, also resulting in a four-membered-ring (Structure III) and 4) through the oxygen and nitrogen of the guanidino group, which forms a seven-membered ring (Structure IV, see Fig. 3).

As is already known from previous studies ${ }^{13}$, the guanidino group is very weakly acidic $(\mathrm{pK}=12-15)$. Thus coordination through its nitrogen atoms is very difficult. This is supported by the fact that in the biosynthesis of creatine, the methyl group, that is transferred to GAA, binds through its nitrogen and not the guanidino group. Besides, arginine, which has a longer alkyl chain than GAA, has nitrogen-oxygen coordination site. Thus Structure III

Table 1. Stability Constants of GAA Complexes.

\begin{tabular}{|c|c|c|c|c|c|c|c|c|c|c|}
\hline \multicolumn{11}{|c|}{$\log K$} \\
\hline \multicolumn{11}{|c|}{ Metal } \\
\hline $\mathrm{p}$ & $\mathrm{q}$ & $\mathrm{r}$ & $1 / \mathrm{H}^{+}$ & $\mathrm{Mn}(\mathrm{II})$ & $\mathrm{Co}(\mathrm{II})$ & $\mathrm{Ni}(\mathrm{II})$ & $\mathrm{Cu}(\mathrm{II})$ & $\mathrm{Zn}(\mathrm{II})$ & $\mathrm{Cd}(\mathrm{II})$ & $\mathrm{Pb}(\mathrm{II})$ \\
\hline 0 & 1 & 1 & $2.90 \pm 0.04$ & - & - & - & - & - & - & - \\
\hline 0 & 1 & 2 & $10.91 \pm 0.07$ & - & - & - & - & - & - & - \\
\hline 0 & 1 & 1 & $2.59 *$ & - & - & - & - & - & - & - \\
\hline 0 & 1 & 2 & $10.85^{*}$ & - & - & - & - & - & - & - \\
\hline 1 & 1 & 0 & - & $5.46 \pm 0.01$ & $5.61 \pm 0.01$ & $5.99 \pm 0.04$ & $7.69 \pm 0.07$ & $7.39 \pm 0.06$ & $5.64 \pm 0.01$ & $6.32 \pm 0.02$ \\
\hline 1 & 2 & 0 & - & $4.96 \pm 0.06$ & $5.12 \pm 0.03$ & $5.65 \pm 0.08$ & $7.51 \pm 0.08$ & $6.93 \pm 0.09$ & $5.25 \pm 0.05$ & $5.58 \pm 0.12$ \\
\hline 1 & 3 & 0 & - & $4.45 \pm 0.05$ & $5.11 \pm 0.05$ & $5.30 \pm 0.11$ & - & - & $4.90 \pm 0.14$ & $5.05 \pm 0.13$ \\
\hline 1 & 1 & 2 & - & $21.30 \pm 0.01$ & $23.61 \pm 0.01$ & $23.95 \pm 0.01$ & $20.96 \pm 0.04$ & $21.30 \pm 0.03$ & $21.16 \pm 0.01$ & - \\
\hline 1 & 1 & -1 & - & $10.34 \pm 0.06$ & $9.32 \pm 0.15$ & $7.37 \pm 0.14$ & $1.04 \pm 0.05$ & - & $9.18 \pm 0.03$ & - \\
\hline 1 & 1 & -2 & - & $19.77 \pm 0.11$ & $18.71 \pm 0.08$ & $15.69 \pm 0.02$ & $-7.00 \pm 0.10$ & $15.69 \pm 0.02$ & $19.21 \pm 0.09$ & - \\
\hline 1 & 1 & -3 & - & $29.16 \pm 0.12$ & $28.56 \pm 0.80$ & - & - & - & - & - \\
\hline 2 & 2 & -1 & - & $11.03 \pm 0.06$ & $10.26 \pm 0.06$ & $6.45 \pm 0.10$ & $3.77 \pm 0.11$ & $6.45 \pm 0.10$ & $11.40 \pm 0.15$ & - \\
\hline
\end{tabular}

1) Symbols and abbreviations used: $\mathrm{p}$ - for metal ion, $\mathrm{q}$ - for ligand, $\mathrm{r}$-for ion hidrogen coefficients and \pm for standard deviation obtained from the calculations using SUPERQUAD program; 2 )* Data from Ref. 13; 3 )All other data refer to potentiometric titrations performed by us at $25{ }^{\circ} \mathrm{C}$ and $\mu=0.1 \mathrm{M}$. 


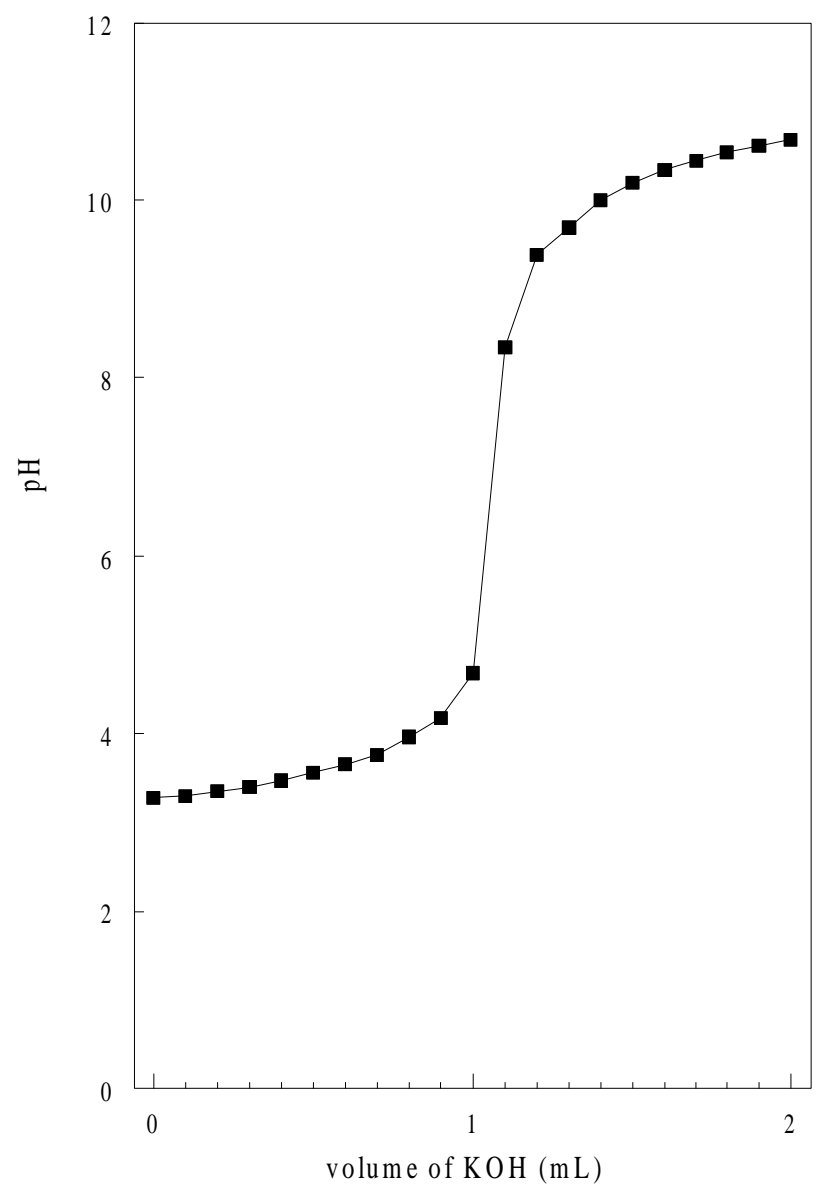

Figure 1. Potentiometric Curve of GAA (1 $\mathrm{mL}$ of $\mathrm{HCl} 0.1 \mathrm{M}$ was added).

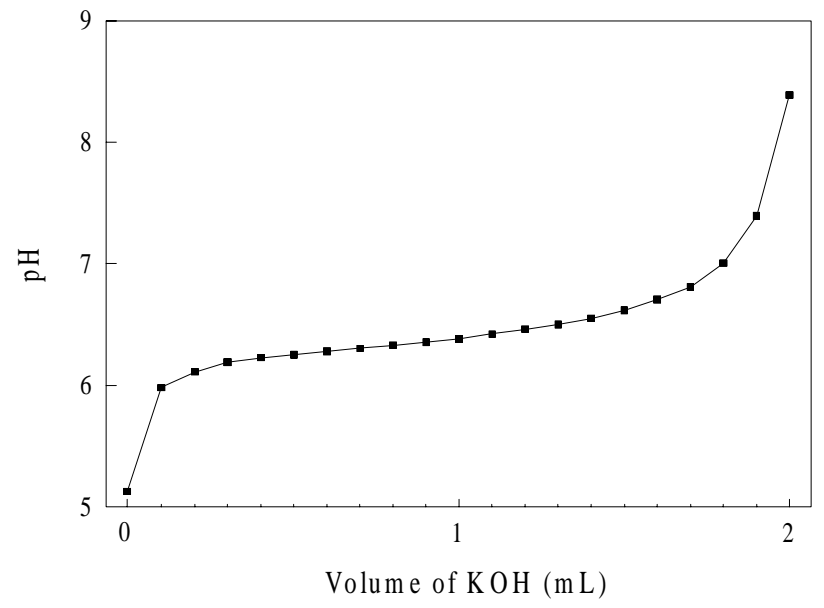

Figure 2. Potentiometric Curve of the System GAA:Cu(II) 1:1.

should be improbable. On the other hand, coordination with two nitrogen atoms should result in MGAA formation constants very different from those of glycine and arginine complexes, which was not observed. Consequently, the four-membered ring of Structure II is not very probable either. Structure IV is a 7-membered-ring which is uncom-

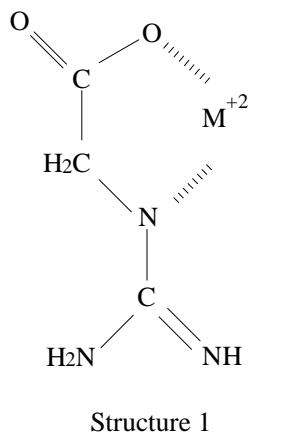<smiles>Cn1[Y12](CC(=O)O)[nH]c1=N</smiles>

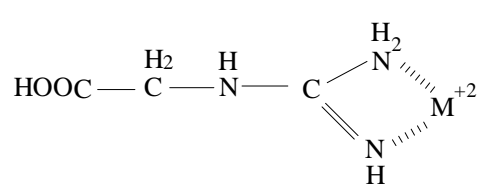

Structure 3
Structure 2<smiles>N=C1N[Y12]OC(=O)CN1</smiles>

Structure 4
Figure 3. Possible Structures of GAA Complexes.

mon. Apparently, Structure I is the most probable, however this will have to be investigated further.

\section{The hydrolysis process}

Studying the beginning of the hydrolysis process is very important in the case of biological ligands such as guanidino acetic acid because this could furnish insight on its role in the human body. Analysis of the species distribution as a function of $\mathrm{pH}$ in the systems studied (except for the lead complexes) shows a remarkable difference of behavior between copper and zinc, on one hand and the other ions (see Figs. 4, 5 and 6). Hydrolysis of MGAA complexes of copper and zinc begins in the $\mathrm{pH}$ range 6-7 while the other MGAA complexes begin to hydrolyse near $\mathrm{pH}$ 8. Thus, it is very obvious that hydrolysis is much easier for copper and zinc complexes. These data, together with the fact that $\mathrm{Cu}$ (II) and $\mathrm{Zn}$ (II) did not form the $\mathrm{ML}_{3}$ and $\mathrm{ML}(\mathrm{OH})_{3}$ species, suggest that these ions formed four coordinate complexes.

$\mathrm{Cu}(\mathrm{II})$ did not form the $\mathrm{M}(\mathrm{GAA})_{3}$ and $\mathrm{MGAA}(\mathrm{OH})_{3}$ species. This can be related to the Jahn-Teller effect that occurs with $\mathrm{d}^{9}$ complexes, distorting the octahedral geometry and resulting in more stable planar complexes. With glycine, $\mathrm{Cu}(\mathrm{II})$ can only form the $\mathrm{CuL}_{3}$ species using a monodentate axial coordination of a third ligand at a very large excess concentration ${ }^{15,16,17}$. Because GAA is a larger ligand than glycine, it is probable that steric effects favour a square geometry for the CuGAA complex. This also might explain why $\mathrm{M}(\mathrm{GAA})_{3}$ and $\mathrm{M}(\mathrm{GAA})(\mathrm{OH})_{3}$ were not observed with $\mathrm{Cu}$ (II). 


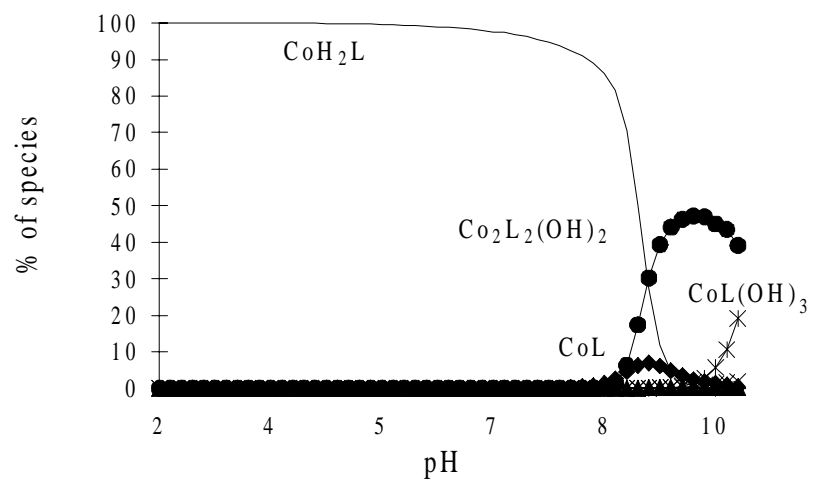

Figure 4. Distribution of Species in the System GAA:Co(II) $1: 1$ as a function of $\mathrm{pH}$.

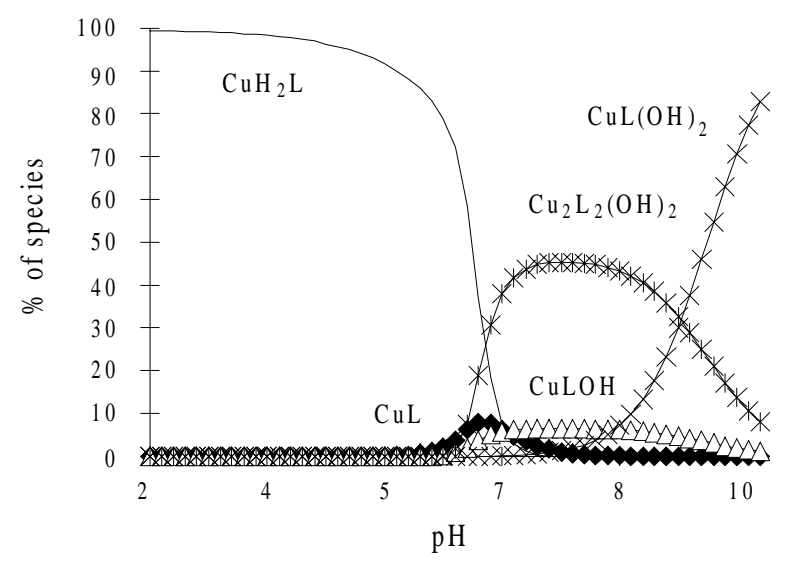

Figure 5. Distribution of Species in the System GAA:Cu(II) $1: 1$ as a function of $\mathrm{pH}$.

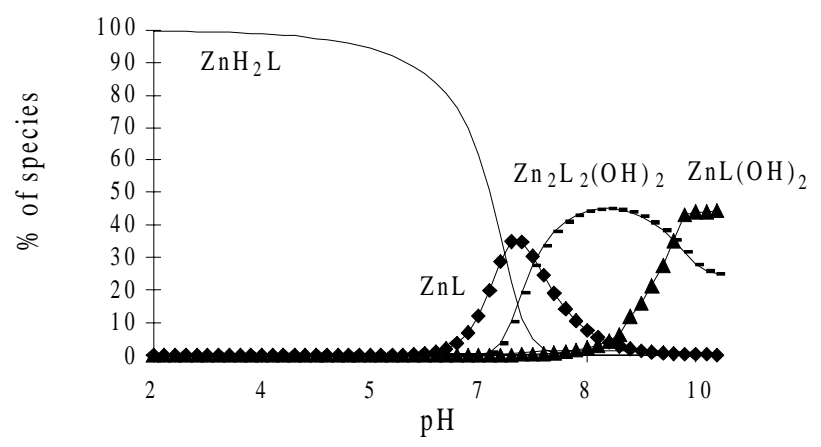

Figure 6. Distribution of Species in the System GAA:Zn(II) 1:1 as a function of $\mathrm{pH}$.

Potentiometric titrations with $\mathrm{Zn}$ (II) and excess of ligand have been done but the formation of $\mathrm{M}(\mathrm{GAA})_{3}$ and $\mathrm{M}(\mathrm{GAA})(\mathrm{OH})_{3}$ was not observed, also indicating tetra-coordination for zinc complexes. The other ions, $\mathrm{Mn}(\mathrm{II})$, $\mathrm{Co}(\mathrm{II}), \mathrm{Ni}(\mathrm{II})$ and $\mathrm{Cd}$ (II) formed $\mathrm{ML}_{3}$ species and their ML complexes begin to hydrolyse at higher $\mathrm{pH}$. Octahedral coordination is most probable for these ions.

\section{Conclusion}

Potentiometric data were employed to calculate formation constants of GAA complexes with the ions $\mathrm{Mn}(\mathrm{II})$,

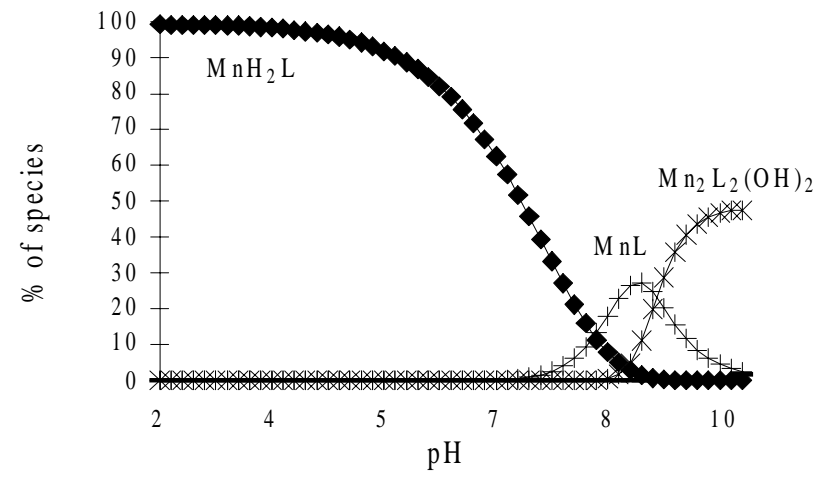

Figure 7. Distribution of Species in the System Mn:GAA 1:1 as a function of $\mathrm{pH}$.

$\mathrm{Co}(\mathrm{II}), \mathrm{Ni}(\mathrm{II}), \mathrm{Cu}(\mathrm{II}), \mathrm{Zn}(\mathrm{II}), \mathrm{Cd}(\mathrm{II})$ and $\mathrm{Pb}(\mathrm{II})$. GAA complexes with $\mathrm{Cu}(\mathrm{II})$ and $\mathrm{Zn}$ (II) behaved differently, compared to the other metal ions. $\mathrm{Cu}$ (II) and $\mathrm{Zn}$ (II) did not form $\mathrm{M}(\mathrm{GAA})_{3}$ nor $\mathrm{M}(\mathrm{GAA})(\mathrm{OH})_{3}$. This can be explained on the basis of the structures of $\mathrm{Cu}(\mathrm{GAA})$ and $\mathrm{Zn}(\mathrm{GAA})$ complexes. They are probably four coordinate complexes, $\mathrm{Cu}(\mathrm{GAA})$ being square and $\mathrm{Zn}(\mathrm{GAA})$, tetrahedral. This behavior is also noticed when the hydrolysis constants of these complexes are analysed. Although $\mathrm{Cu}$ (II) and $\mathrm{Zn}$ (II) had greater ML formation constants, they also have greater hydrolysis constants because of their geometries. The expected variation - greater ML formation constants, smaller hydrolysis constants - was observed for the other ions. The hydrolysis of CuGAA and ZnGAA begins near pH 6-7, while for the other MGAA complexes it begins near $\mathrm{pH} 8$. The other GAA complexes may have octahedral structures, forming chelates of five members similar (or almost) to the case of glycine. During the titration of the GAA-Pb(II) complex a large quantity of precipitate of polymeric hydrolysed species was formed.

The obseved data suggests that the guanidino group does not coordinate with the ions studied. However, it is very important in the complexation process inasmuch as it has a great influence on the stereochemistry and stability of the complexes formed. In addition it can decrease the basicity of the -amino group. It is planned to compare the results of this potentiometric study with the results of other techniques for GAA complexes in an attempt to confirm and enhance the above conclusions.

\section{Acknowledgments}

The authors gratefully acknowledge the Brazilian Ministry of Science and Technology (MCT) and the Brazilian National Research Council (CNPq).

\section{References}

1. Takeda, M. Japan J. Nephrol. 1990, 32 (2), 117-26.

2. Sugyiama, K.; Ohishi, A.; Siyo, H.; Takenchi, H. J.

Nutr. Sci. Vitaminol. 1989, 35 (6), 613-26 .

3. Ikezaki, N. Jpn. J. Nephrol. 1990, 32(3), 283-90. 
4. Kellog M.S.; Klade C.; Madigan D.; Mazul, R.H.; Muller G.W. Ac. Symp. Ser. 1991, 450, 100-112.

5. Du Vigneaud; Cohn, M.V.; Chandler, J.P.; Schenk, J.R.; Simmond, S. J. Biol. Chem. 1941, 140, 625.

6. Cohen, S. J. Biol. Chem.1951, 93, 851.

7. Hirata M. Jpn. J. Nephrol.1989, 31 (9), 951-961.

8. Horning, E.C. In Organic Syntheses Collective, Ed.; John Wiley and Sons Inc., London, 1955, vol. 3, 440-442.

9. Martell, A.E. In Determination and Use of Stability Constants; Motekaitis, R.J., Ed.; VCH Publishers, U.S.A., 1992.

10. Gans, P.; Sabatini, A.; Vacca, A. J. Chem. Soc. Dalton Trans. 1985, 1195-1200.
11. Burger, K. In Biocoordination Chemistry: coordination equilibria in biologically active systems, Ed.; Ellis Horwood, England, 1990.

12. Wilson, E.W.; Martin, R.B. Inorg. Chem.1970, 9, 528.

13. Mittal, R.K.; Chandra, C.M; Dey, A.K. Monatsh Chem. 1978, 9, 953.

14. Clarke, E.R.; Martell, A.E. J. Inorg. Nucl. Chem. 1970, 32, 911 .

15. Gotsis, E.D.; Fiat, D. Polyhedron 1987, 12, vol. 6, 2053-2065.

16. Nagypál, I.; Debreczeni, F.; Cornick, R.E. Inorg. Chim. Acta 1981, 48, 225.

17. Nagypál, I.; Debreczeni, F.; Erdõdi, F. Inorg. Chim. Acta 1982, 57, 125.

18. Smith, R.M.; Martell, A.E. In Critical Stability Constants, New York, 1982, Vols 1-5, 1974-77. 